УДК 130.1:17.023.33

DOI https://doi.org/10.32837/apfs.v0i32.1029

О. І. Павлов

ORCID ID: https://orcid.org/0000-0001-6431-5210

доктор економічних наук, професор,

завідувач кафедри економіки пролисловості

Одеського національного технологічного університету

\title{
НІЦШЕАНСЬКИЙ ОБРАЗ НАДЛЮДИНИ ТА СУЧАСНІСТЬ
}

Постановка проблеми. Доля творчої спадщини $\Phi$. Ніцше переконує у справедливості єсенінського виразу про те, що «велике бачиться на відстані». I це передусім стосується ідеї Ф. Ніцше про надлюдину, викладену у його найбільш відомій праці «Так казав Заратустра». Відтоді минуло понад 130 років, але інтерес до філософських надбань цього мислителя не згасає.

Ця книга має глибинний підтекст, що міститься у її підназві: «Для всіх і ні для кого». Саме під час задуму цього твору Ф. Ніцше перебував у тривалій депресії, викликаною його хворобливим станом. Звідси - форма подання матеріалу у вигляді філософської сповіді для себе, за якою були приховані фізична біль і моральні страждання. Все це надихнуло його до роздумів щодо необхідності досягнення людиною внутрішньої гармонії: за допомогою власної сили волі, зуміти реалізувати своє істинне «я», працюючи над собою, фактично відкрити його у собі. На думку Ф. Ніцше, цього можливо досягти за рахунок волі до влади над собою.

Цей основоположний лейтмотив твору Ф. Ніцше не втратив своєї теоретичної актуальності та практичної значущості й на сучасному етапі глобалізації при переході від інформаційнол-комунікативних технологій п'ятої хвилі до когнітивно-кібернетичних технологій шостої хвилі.

Ніцшеанський погляд на надлюдину з метафізичної, релігійної, антропологічної та соціальної позицій зіставний із відповідними уявленнями К. Ясперса та вимагає також його розгляду в контексті вчення В. Вернадського про ноосферну людину та трансгуманістичний (постгуманістичний) образ людини з машини, який постає як футурологія, дотична напівреалістичним, напівміфологічним перспективам осягнення технологічної сингулярності.

Аналіз останніх досліджень і публікацій. Ідея Ф. Ніцше про надлюдину, як і понад століття тому, не сходить зі сторінок зарубіжних і вітчизняних наукових видань, про що свідчить стаття Л. Павлишин, у якій подано аналіз творчої спадщини німецького філософа дослідниками XX XXI століть [1]. Звертаючи увагу на значення філософських поглядів Ф. Ніцше для сьогодення, його співвітчизник Ф. Юнгер зазначає, що велика філософія не пристосовується не тільки до поточних полі- тичних ситуацій, а й до епох [2, с. 106]. Цю думку поділяє О. Дугін, відзначаючи, що вся філософія XX століття була нічим іншим, як коментарем до Ф. Ніцше, тому що він сповістив людство про прихід надлюдини [3]. В. Кучевський, аналізуючи заперечення $\Phi$. Ніцше розумного начала як у світі, так і в людині, пояснює це ірраціоналізмом філософських роздумів філософа [4, с. 17]. С. Франк розкриває моральну систему німецького вченого через його заперечення моралі тогочасного суспільства [5, с. 21]. Різні аспекти ніцшеанської ідеї про надлюдину досліджуються Д. Харченко [6], Н. Осіповою [7], Н. Яровицькою та Л. Касинюк [8], А. Сомовим [9]. Вплив «перспективізму» $\Phi$. Ніцше на сучасні стандарти прав людини представлено у публікації Д. Бочарова [10]. М. Ожеван і Дубов Д. досліджують проблему еволюції людини в умовах розгортання Четвертої та П' ятої індустріальних революцій [11], яка виходить далеко за межі наукового пошуку Ф. Ніцше.

3 огляду на здійснений аналіз наукових джерел тема статті є актуальною.

Метою статті є розкриття, через осмислення ніцшеанського образу надлюдини, сенсу буття людини, яка за покликанням долі має перебувати у постійному русі на шляху самовдосконалення не тільки тіла, а й духу та розуму.

Виклад основного матеріалу. У передмові книги Ф. Ніцше міститься сентенція: «Людина - це канат, натягнутий між твариною і надлюдиною. Канат над прірвою. Небезпечно проходження, небезпечно бути в дорозі, небезпечний погляд, звернений назад, небезпечні страх і зупинка...» [12].

Автор порівнює себе з духом, котрий бродить по льодовику (потік крижаної води, що спускається з гір), - у тих висях, де не здатний вижити ніхто. Гора у Ф. Ніцше - символ духовної висоти, яка є доступною лише обраним.

Виходячи з цього, стає зрозумілим зміст фрази: «Людина як канат <...> над прірвою» [12]. Звідси - асоціація людини, що намагається перевершити себе, з канатоходцем, що перебуває на кордоні між небом і землею, божественним i диявольським, людиною, яка не стала на канат, і надлюдиною, котра пройшла по ньому до кінця.

Однією із центральних ідей твору є думка про те, що людина - проміжний ступінь у перетворенні 
мавпи на надлюдину: «Людина - це канат, натягнутий між твариною і надлюдиною. Канат над безоднею» [12] (рис. 1).

На рис. 1 наведено термінологію із книги Л. Гумільова «Етногенез та біосфера Землі» . Ефект енергії живої речовини, за Л. Гумільовим, проявляється у стимулах до тієї чи іншої діяльності. Це матеріалізована у людських вчинках енергетична зарядженість, реалізована у біомасі. У цьому сенсі не тільки кожен етнос, а й окрема особистість має свій власний, відмінний від інших, запас енергії та, відповідно, рівень пасіонарності та певний стереотип поведінки.
Розглядаючи пасіонарність на рівні інстинкту, Л. Гумільов протиставляв пасіонарному імпульсу інстинкт самозбереження [13, с. 265], співвідношення яких впливає на здатність людини до «переходу» від тварини до надлюдини. За вказаною ознакою він поділяє представників людської спільноти на пасіонаріїв, гармонійних осіб і субпасіонаріїв (табл. 1).

Людина, на думку Ф. Ніцше, повинна пройти три ступені духовного розвитку (табл. 2).

Але що може зробити дитина, чого не міг би навіть лев? Чому хижий лев повинен стати ще дитиною? Дитя є невинність і забуття, нове починання,
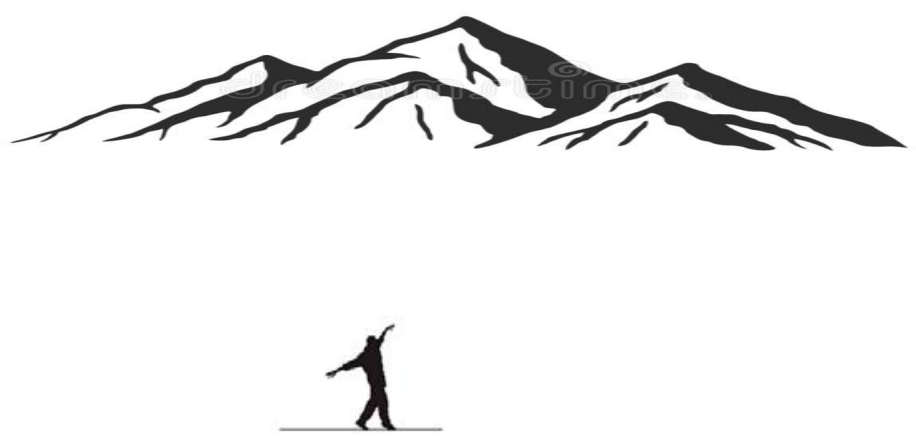

$\mathrm{T}$

Пасіонарна особа

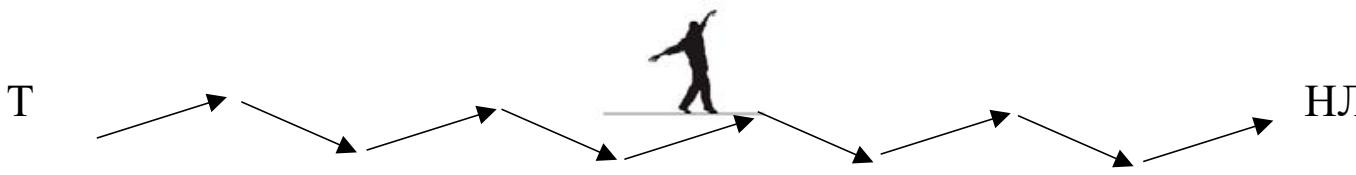

Гармонійна особа

$\mathrm{T}$

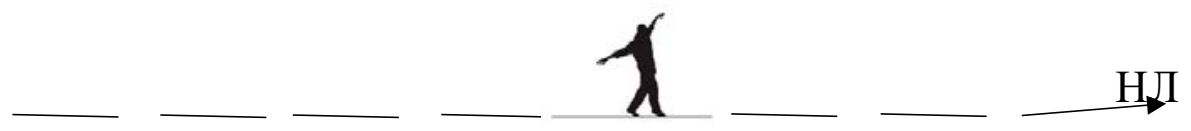

Асоціальна особа

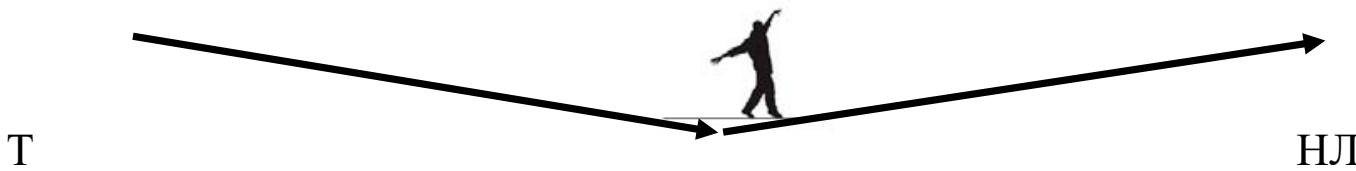

Субпасіонарна особа

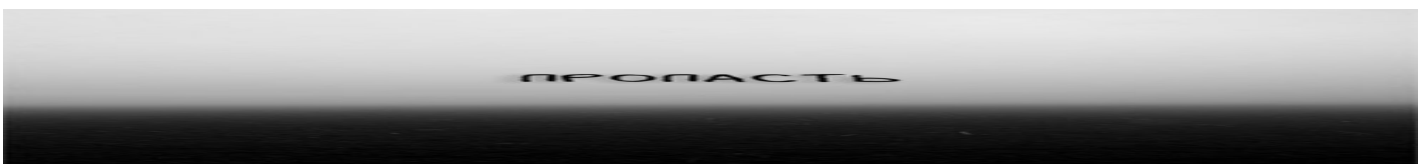

Рис. 1. «Перехід» людини від тварини (Т) до надлюдини (НЛ)

Джерело: складено з використанням: [12; 13, с. 265]. 
Типи представників людських спільнот*

Таблиця 1

\begin{tabular}{|c|c|c|}
\hline Тип людини & $\begin{array}{c}\text { Ознака класифікації } \\
\text { (ступінь соціальної активності) }\end{array}$ & Сутнісна характеристика типу \\
\hline Пасіонарний & Сильна & $\begin{array}{c}\text { Це люди, у яких пасіонарний імпульс сильніший, } \\
\text { ніж інстинкт самозбереження }\end{array}$ \\
\hline Гармонійний & Середня & $\begin{array}{c}\text { Це переважна частина людської спільноти, } \\
\text { у якої енергетичний пасіонарний імпульс та інстинкт } \\
\text { самозбереження врівноважені, що утворює гармонійну } \\
\text { особистість, яка є м’якою, але не надактивною }\end{array}$ \\
\hline $\begin{array}{c}\text { Асоціальний } \\
\text { (авторська класификація } \\
\text { та визначення) }\end{array}$ & $\begin{array}{c}\text { Обмежена правом або } \\
\text { фізіологічним станом } \\
\text { организму }\end{array}$ & $\begin{array}{c}\text { Це люди, виключені з різних причин назавжди або тимчасово, } \\
\text { з повсякденного життя суспільства }\end{array}$ \\
\hline Субпасіонарний & Слабка & $\begin{array}{c}\text { Це люди, у яких інстинкт самозбереження перевищує } \\
\text { пасіонарний імпульс }\end{array}$ \\
\hline
\end{tabular}

* Джерело: складено і доповнено на основі: [13, с. 265].

Таблиця 2

Ступені духовного розвитку людини*

\begin{tabular}{|c|c|c|}
\hline $\begin{array}{c}\text { Ступень духовного } \\
\text { розвитку }\end{array}$ & $\begin{array}{c}\text { Ознака класифікації } \\
\text { (ступінь олюднення) }\end{array}$ & Сутнісна характеристика ступеня духовного розвитку \\
\hline «Верблюд» & Низька & Людина, що навантажена традиціями й установками культури \\
\hline «Лев» & Середня & $\begin{array}{c}\text { Людина, яка заперечує себе як верблюда, тобто відмовляється } \\
\text { від усього того, від чого вона залежить }\end{array}$ \\
\hline «Дитина» & Висока & $\begin{array}{c}\text { Людина, відкрита для всього нового, чистий аркуш, сама } \\
\text { встановлює собі закони та керує своєю волею }\end{array}$ \\
\hline
\end{tabular}

* Джерело: складено і доповнено на основі: [12].

гра, саме колесо, що котиться, початковий рух, святе слово твердження. Так, для гри творення, потрібно святе слово твердження: своєї волі хоче тепер дух, свій світ знаходить втрачений світ. Три перетворення духу назвав я вам: як дух став верблюдом, левом верблюд i, нарешті, лев дитиною, зазначає Ф. Ніцше [12].

Тільки від духовної установки людини залежить, до якого ступеня розвитку вона дійде. Як відомо, духовні якості людини є результатом виховання, історичного й особистого досвіду та не успадковуються, на відміну від фізіологічних і психологічних властивостей, тому вони досить рухливі та мінливі. Недарма К. Ясперс порівнював духовний лад людини з тонкою оболонкою над кратером вулкану. Може трапитися так, що ця оболонка буде скинута, що загрожує людській спільноті оберненням на людей кам'яного віку [14, с. 56].

Людина, за Ф. Ніцше, є щось, що має перевершити. Що зробили ви, щоб перевершити іiї? Bci icтоти досі створювали щось вище себе, а ви хочете бути відпливом цієї хвилі та швидше повернутися до стану звіра, ніж здолати людину? [12] (рис. 2).

Доктрині прогресу (поступального розвитку), яка панувала в умах європейців із настанням епохи Просвітництва, Ф. Ніцше протиставив вчення про вічне повернення, про циклічність будь-якого розвитку. Тільки надлюдина здатна з готовністю прийняти нескінченне повернення одного разу пережитого, включаючи самі гіркі хвилини. Відмінність такої істоти від звичайної людини, по Ніцше, - у порядку відмінності людини від мавпи.
Ф. Ніцше досліджує надлюдину не як антропологічний, а як багатовимірний феномен, із метафізичної, релігійної, антропологічної і соціальної позицій.

Порівнюючи надлюдину з людиною, Ф. Ніцше вказував, що «людина є щось, що має перевершити». Він порівнює людини з мавпою і з надлюдиною з позицій еволюційної теорії Ч. Дарвіна: «Що таке мавпа щодо людини? Посміховисько або нестерпний сором. I тим самим має бути людина для надлюдини: посміховиськом або нестерпним соромом» [12].

Думка Ф. Ніцше про те, що людину слід розглядати у ракурсі тіла та тваринного начала, зовсім не означає, що людина походить від тварини. Тваринне начало у людині має більш глибоку метафізичну основу, ніж та, яку можна було би визначити з науково-біологічного погляду.

Якщо Христос як Боголюдина прийшов заради порятунку людини, то Ф. Ніцше суттю Землі проголошує надлюдину й одночасно говорить про смерть Бога. Явище надлюдини і смерть Бога взаємопов'язані. Одночасно Ф. Ніцше проклинає всіх, хто сповіщає про надземні надії.

Згідно із Ф. Ніцше надлюдина займе місце Бога, який багато століть поспіль грав роль потішача для слабких і скривджених.

У найбільш загальному уявленні надлюдина це той, хто живе відповідно до вимог своєї природи.

Надлюдина - це людина, котрій вдалося подолати роздрібненість свого існування, котра повернула собі світ і підняла погляд над його горизонтом. 
Надлюдина, за словами Ф. Ніцше, - це суть Землі, у ній природа знаходить своє онтологічне виправдання. На противагу їй, остання людина представляє виродження людського роду, живе у повному забутті своєї суті, віддавши її на відкуп звірячому перебуванню в комфортних умовах.

Як людина перевершує мавпу, так надлюдина перевершує людину. «Вища людина» або «найкраща людина» виступає, з одного боку, провісником надлюдини, іï прабатьком, з іншого - подібно до кокона шовкопряда, вища людина точно так же повинна бути знищена, щоб народилася надлюдина.

Ніцше намагався відкрити новий стан людського духу - надлюдини, якій властиві певні риси (рис. 3).

Для $\Phi$. Ніцше надлюдина - це результат культурно-духовного вдосконалення людини, тип, що набагато перевищує сучасну людину за своїми інтелектуально-моральними якостями.

$\Phi$. Ніцше мислив появу надлюдини як довгий процес самовизначення, як торжество духовної природи людини.

У світлі вчення Ф. Ніцше про надлюдину остання - це образ-метафора, евристика автора. Тому шукати закінченого портрета, як і домислювати його, замість автора, не має сенсу. Ідея надлюдини - відкритий проект, що дає простір для польоту думки, котрі не дають ніяких готових думок. Кожен сам вільний наповнювати «посудину» надлюдини власним змістом.
Із філософів XX століття, котрі наблизилися до розуміння творчої лабораторії $\Phi$. Ніцше, був К. Ясперс, який бачив у ньому попередника екзистенційної філософії та намагався осмислити його тексти як відображення досвіду прикордонного існування, у якому і відбувається зустріч людини з буттям: «Мислення Ніцше іноді може здатися порожнім, а іноді досягає справжніх глибин. Воно порожне, коли той, хто звертається до нього, хоче мати те, що дійсно й існує; у ньому є повнота, коли він бере участь у русі» [15, с. 189].

Недарма концепція «осьового часу» К. Ясперса грунтується на визнанні ним духовного прориву, пов'язаного з переоцінкою людиною певних цінностей, її виходом за межі свого індивідуального існування, усвідомленням нею свого призначення як самоцінної особи, виникненням раціонального мислення [14, с. 33].

3 інших позицій до оцінки сутнісних характеристик людини майбутнього підійшов В. Вернадський. В основі його вчення про людину ноосфери лежить натуралізм, біологічна еволюція та геологічний процес, який визначає майже всі параметри людини: ï анатомію, фізіологію, нервову систему, фізичні дані, розумову та трудову діяльність. Інакше кажучи, йдеться про людину розумну як вид тваринного світу та частину живої речовини. У цьому сенсі його уявлення щодо людської природи деякою мірою збігаються із поглядами Ф. Ніцше.

\begin{tabular}{|l|l|}
\hline 1. & $\begin{array}{l}\text { Розірвати пута несвободи та забобонів, піднятися над самим собою все вище і вище по щаблях духу, переживаючи } \\
\text { житя із граничною силою напруги пристрасті (спорідненість із концепцією етногенезу Л. Гумільова) }\end{array}$ \\
\hline 2. & $\begin{array}{l}\text { Вищим типом особистості є надлюдина, що стряхнула прах помилкових цінностей, вільна духом і серцем, } \\
\text { сповнена волі (мощі енергії) до життя, невтомна в русі вгору, до свого істинного «я» }\end{array}$ \\
\hline 3. & $\begin{array}{l}\text { Надлюдина - категорія не соціальна, національна, а духовна - це прообаз межі, який доступний розвитку } \\
\text { особистості (зв’язок з ідеями Е. Фромма й А. Шопенгауера) }\end{array}$ \\
\hline 4. & $\begin{array}{l}\text { Людське прагнення до мети перевершити людину сприяє народженню нової аристократії, супротивниці всього, } \\
\text { що є натовп і всякий деспотизм, яка на нових скрижалях знову напише слово «шляхетний» } \\
\text { (аристократ духу, а не титулований) }\end{array}$ \\
\hline
\end{tabular}

Рис. 2. Що означає, за Ф. Ніцше, «перевершити людину»

Джерело: складено і доповнено на основі: [12].

\begin{tabular}{|l|l|}
\hline 1. & Це особистість, яка керує власним досвідом, створює власну долю \\
\hline 2. & Це «аристократ» духу. Людина натовпу ніколи не стане надлюдиною \\
\hline 3. & Вона не залежить від Бога, від громадських та історичних обмежень \\
\hline 4. & $\begin{array}{l}\text { Головна цінність - «благородне», то, що стоїть «по той бік добра і зла». } \\
\text { Ніцше протестує проти інстинктів життя обивателя. Він повинен подолати все дріб’язкове та ганебне, зробити прорив } \\
\text { до вершини людського духу. І це сходження є шлях «назустріч своєму вищому страждання і своєї вищої надії» }\end{array}$ \\
\hline 5. & Життя - постійна боротьба. Треба вільно йти назустріч життю і мужньо заглянути в обличчя смерті \\
\hline 6. & $\begin{array}{l}\text { Мета життя - у творчій праці, творенні, пошуку істини, у подоланні самого себе, але на це здатні не всі, } \\
\text { а лише ті, хто наділений «волею до могутності. По суті, це заклик Ніцше до саморуйнування «тварі» у людині } \\
\text { для самотворення у ньому «творця» }\end{array}$ \\
\hline $\begin{array}{l}\text { Ф. Ніцше } \\
\text { про себе }\end{array}$ & $\begin{array}{l}\text { Так, я знаю, знаю, хто я: Я, як полум’я, чужий спокою. Палю, згораючи і поспішаючи. Охоплю - блиск чуда, } \\
\text { Відпущу - і попелу купа. Полум’я - ось моя душа }\end{array}$ \\
\hline
\end{tabular}

Рис. 3. Прояви надлюдина як новий стан людського духу

Джерело: складено і доповнено на основі: [12]. 
Водночас В. Вернадський зазначав, що у XX столітті «біосфера набуває абсолютно нового розуміння. Вона виявляється як планетне явище космічного характеру. У біогеохімії нам доводиться зважати на те, що життя (живі організми) реально існує не тільки на одній нашій планеті, не тільки в земній біосфері. Це встановлено зараз, на мою думку, без сумнівів поки для всіх так званих “земних планет”, тобто для Венери, Землі та Марса» [16].

Глибоким і співзвучним ідеї $\Phi$. Ніцше про надлюдину є висновок В. Вернадського про те, що «у геологічній історії біосфери перед людиною відкривається величезне майбутнє, якщо вона зрозуміє це і не вживатиме свій розум і свою працю на самознищення» [16].

На цьому тлі цілком зрозумілими постають технодетерміновані образи людини й соціуму, релевантні епосі нового індустріалізму. Сучасні технології, як стверджує К. Шваб, матимуть наслідком посилення впливу машинних технологій на першоприродну людську сутність і до невпізнаваності змінять (а, можливо, й підмінять, як попереджають мислителі-алармісти) біологічну природу людського тіла. Техніка та технології не лише стануть продовженням і доповненням людської природи ззовні, але й проникнуть усередину людської тілесності й людської «душі» [17].

Зіставляючи наукові уявлення щодо досконалої людині Ф. Ніцше з уявленнями сучасних мислителів, слід зазначити, що вони не суперечать одне одному, так само, як і не вичерпують повної характеристики людини майбутнього.

Висновки. Оцінюючи значення ніцшеанського образу надлюдини для сучасності, потрібно розуміти, що Ф. Ніцше був несвоєчасною людиною для своєї епохи. Епоха жила вірою у прогрес, він же розглядав своє справжнє як минуле, шукав опору в ідеальному світі, що для людини його часу було обманом, а те, що сучасниками Ф. Ніцше сприймалося як норма, для нього було лицемірством.

Лицемірство епохи він розглядав як виклик, тому не хотів вводити в оману себе й оточуючих. 3 цієї причини можна цілком довіряти характеристиці, яку він надав європейському суспільству кінця XIX століття.

Саме тому сучасна людина відчуває потребу в осягненні творчої спадщини Ф. Ніцше, передусім тієї її частини, яка стосується ідеї удосконалення людських якостей. Ф. Ніцше проголосив неминуче, потрібне, неможливе. Він сповістив нас про прихід надлюдини. Цей прихід значно збільшив кількість людської спільноти, яка готова встати на канат і йти до кінця - до перемоги над собою.

Оскільки ідея всебічного удосконалення сучасної людини набула вселенського значення, іiї системне дослідження потребує зосередження уваги вчених на міждисциплінарному підході, що i є одним із перспективних напрямів здійснення подальших наукових розвідок.

\section{Jimepamypa}

1. Павлишин Л.Г. Основні ідеї Ф. Ніцше у працях дослідників його творчості. Актуальні проблеми філософії та соиіологіï. 2020. № 27. С. 43-47.

2. Юнгер Ф.Г. Ницше / пер. с нем. А.В. Михайловского. Москва : Праксис, 2001. 256 с.

3. Дугин А.Г. Фридрих Ницше: путь к сверхчеловеку. URL: https://paideuma.tv/video/fridrihnicshe-put-k-sverhcheloveku-aleksandr-dugin-finismundi\#/?playlistId $=0 \&$ videoId $=0$ (дата $\quad$ звернення: 18.11.2021).

4. Кучевский В.Б. Философия нигилизма Ф. Ницше. Москва, 1996. 166 с.

5. Франк С.Л. Ницше и этика «любви к дальнему». Приложение к журналу «Вопросы философии». Москва : Правда, 1990. С. 21-29.

6. Харченко Д. Сверхчеловек: социальное измерение и динамика. Власть. 2012. № 1. С. 87-90.

7. Осипова Н. «Канатоходцы» серебряного века. URL: https://bazhum.muzhp.pl/media/ files/Polilog_Studia_Neofilologiczne/Polilog Studia_Neofilologiczne-r2015-t-n5/Polilog_Studia_ Neofilologiczne-r2015-t-n5-s107-117/Polilog_Studia_ Neofilologiczne-r2015-t-n5-s107-117.pdf - (дата звернення: 15.10.2021).

8. Яровицька Н., Касинюк Л. «Остання людина» як трансгресія до «надлюдини». Вісник Львівського унту. Серія «Філософсько-політологічні студї». 2018. Вип. 17. С. 103-108.

9. Сомов А.Ю. Генеза ідеї надлюдини в європейській філософії: концепція Фрідріха Ніцше. Грані. 2015. № 5 (121). С. 109-116.

10. Бочаров Д. «Перспективізм» Ф. Ніцше та його вплив на сучасні стандарти прав людини. Права людини: філософські, теоретико-юридичні та політологічні виліри : Статті учасників I Міжнародного круглого столу (м. Львів, 28-29 жовтня 2016 р.). Львів : Видавництво ЛОБФ «Медицина і право», 2017. С. 20-46.

11. Ожеван M.A., Дубов Д.В. Ноmo ex Machina. Філософські, культурологічні та політичні передумови формування конвергентного суспільства : монографія. Київ : НІСД, 2017. 272 с.

12. Ніцше Ф. Так казав Заратустра. Книжка для всіх і ні для кого. URL: https://www.ukrlib.com.ua/world/ printit.php?tid=3781 (дата звернення: 11.09.2021).

13. Гумилев Л.Н. Этногенез и биосфера Земли. Москва : Айрис-Петри, 1989. 560 с.

14.Ясперс К. Смысл и назначение истории / пер. с нем. Москва : Политиздат, 1991. 527 с.

15. Ясперс К. Ницше. Введение в понимание его философствования. Санкт-Петербург : Владимир Даль, $2004.632 \mathrm{c}$.

16. Вернадский В.И. Несколько слов о ноосфере. URL: http://vernadsky.lib.ru/e-texts/archive/noos. $\mathrm{html}$ (дата звернення: 17.11.2021).

17. Schwab Klaus. The Fourth Industrial Revolution: what it means, how to respond URL: https://www. weforum.org/agenda/2016/01/thefourth-industrialrevolution-what-it-means-and-how-to-respond/ (дата звернення: 13.11.2021). 


\section{Анотація}

Павлов O. I. Ніцшеанський образ надлюдини та сучасність. - Стаття.

У статті розкрито ніцшеанський образ надлюдини, яка за покликанням долі має перебувати у постійному русі на шляху самовдосконалення не тільки тіла, а й духу та розуму, чого, на думку Ф. Ніцше, можливо досягти за рахунок волі до влади над собою. Доведено, що тільки від духовної установки людини залежить до якого ступеня розвитку вона дійде. Звідси випливає розуміння надлюдини як людини, котрій вдалося подолати роздрібненість свого існування, котра повернула собі світ і підняла погляд над його горизонтом.

Основні результати дослідження грунтуються на філософському положенні, яке відбилося у праці $\Phi$. Ніцше, про те, що духовні якості людини є результатом виховання, історичного й особистого досвіду та не успадковуються, на відміну від фізіологічних і психологічних властивостей, тому вони досить рухливі та мінливі. Мета життя полягає у пошуку істини, творчій праці, подоланні себе.

Простежується зв'язок цього основоположного лейтмотиву твору Ф. Ніцше із сучасним етапом розвитку людства, яке переживає перехід від інформаційно-комунікативних технологій п'ятої хвилі до когнітивно-кібернетичних технологій шостої хвилі. 3'ясовано зв'язок ідеї Ф. Ніцше про надлюдину 3 концепцією «осьового часу» К. Ясперса, вченням В. Вернадського про ноосферну людину, із трансгуманістичним техніко-детермінованим образом людини 3 машини та їх впливом на формування досконалої людини. Актуальність ідеї Ф. Ніцше про надлюдину підтверджується спостереженням В. Вернадського щодо того, що людина матиме величезне майбутнє, якщо вона не вживатиме свій розум і свою працю на самознищення.

Зроблено висновок, що уявлення Ф. Ніцше про надлюдину не суперечить науковим поглядам сучасних мислителей про шляхи та напрями еволюції людини розумної. Саме тому сучасна людина відчуває потребу в оволодінні творчою спадщиною Ф. Ніцше щодо удосконалення людських якостей. Ф. Ніцше проголосив неминуче, потрібне, неможливе. Він сповістив нас про прихід надлюдини. Цей прихід значно збільшив кількість людської спільноти, готової стати на канат і йти до кінця - до перемоги над собою. Обгрунтовуючи значення ніцшеанського образу надлюдини для сучасності, потрібно розуміти, що $\Phi$. Ніцше був несвоєчасною людиною для своєї епохи. Епоха жила вірою у прогрес, він же розглядав своє справжнє як минуле, шукав опору в ідеальному світі. Сучасний світ є далеко не ідеальним, тому існує нагальна потреба у послідовниках творчих пошуків німецького філософа.

Оскільки ідея всебічного удосконалення сучасної людини набула вселенського значення, її осягнення потребує зосередження уваги вчених на міждисциплінарному підході, що і є одним із перспективних напрямів здійснення подальших наукових розвідок.

Ключові слова: людина як канат, натягнутий між твариною та надлюдиною, людський дух, ніцшеанський образ надлюдини, ноосферна людина, образ людина з машини, «осьовий час».

\section{Summary}

Pavlov O. I. Nietzschean image of the superman and present. - Article.

The article reveals the meaning of Nietzsche's image of the superman, which, by vocation of destiny, must be in constant motion on the path of self-improvement not only body but also spirit and mind, which, according to F. Nietzsche, can be achieved by the will to power over yourself. It is proved that only the spiritual attitude of a person depends on the degree of development he will reach. Hence the understanding of the superman as a man who managed to overcome the fragmentation of his existence, who regained the world and looked up over its horizon.

The main results of the study are based on the philosophical position, which is reflected in the work of Nietzsche, that the spiritual qualities of man are the result of education, historical and personal experience and are not inherited in contrast to physiological and psychological properties, so they are quite mobile and changeable. In this sense, the purpose of life is to find the truth, creative work, overcoming yourself.

The connection of this fundamental leitmotif of F. Nietzsche's work with the modern stage of human development, which is going through the transition from information and communication technologies of the fifth wave to cognitive and cybernetic technologies of the sixth wave, is traced. The connection is clarified of Nietzsche's idea of the superman with K. Jaspers' concept of "axial time", W. Vernadsky's doctrine of the noosphere man, with the transhumanist technically determined image of man from the machine and their influence on the formation of a perfect man. The relevance of Nietzsche's idea of the superman is confirmed by W. Vernadsky's observation that man will have a great future if he does not use his mind and his work for self-destruction.

It is concluded that F. Nietzsche's idea of the superman does not contradict the scientific views of modern thinkers about the ways and directions of evolution of intelligent man. That is why modern man feels the need to master the creative heritage of F. Nietzsche to improve human qualities. F. Nietzsche proclaimed the inevitable, necessary, impossible. He informed us of the coming of the superman. This arrival has greatly increased the number of people who are ready to get on the rope and go to the end - to victory over themselves. Substantiating the significance of Nietzsche's image of the superman for modernity, we must understand that Nietzsche was an untimely man for his time. The epoch lived faith in progress, he considered his present as the past, sought support in an ideal world. The modern world is far from perfect, so there is an urgent need for followers of the creative search of the German philosopher.

Since the idea of comprehensive improvement of modern man has acquired planetary significance, its comprehension requires the focus of scientists on an interdisciplinary approach, which is actually one of the promising areas of further scientific research this problem.

Key words: man as a rope stretched between an animal and a superman, human spirit, Nietzschean image of the superman, noosphere man, image of a man from a machine, "axial time". 